\title{
PENYELESAIAN KASUS HUKUM DI LINGKUNGAN PENGADILAN MILITER DALAM PERKARA TINDAK PIDANA PENIPUAN YANG DILAKUKAN OLEH ANGGOTA TNI
}

\author{
Rinaldi Chandra \\ Fakultas Hukum Universitas Pamulang \\ tamanyasmin98@gmail.com
}

\begin{abstract}
The scientific method is carried out through careful and complete investigation of all the evidence that can be obtained about a particular problem so that a solution can be obtained for that problem. The research method is a scientific activity, which is based on certain methods, systematic, and thinking, which aims to study one or several legal phenomena, by analyzing them. The author uses this type of dexirptif research because the writer wants to obtain a clear picture and provide accurate data regarding the settlement of fraud cases committed by members of the TNI. Article 9 of Law No. 31 of 1997 concerning Military Courts, assembled with Articles 1 and 2 of the Military Criminal Law Act (KUHPM), the Military Courts adjudicate crimes based on their subjects, namely soldiers (military) or the equivalent.
\end{abstract}

Keywords: Law, Technology, Online Tranfortation

\begin{abstract}
ABSTRAK
Metode ilmiah yang dilakukan melalui penyelidikan dengan seksama dan lengkap, terhadap semua bukti-bukti yang dapat diperoleh mengenai suatu permasalahan tertentu sehingga dapat diperoleh suatu pemecahan bagi permasalahan itu. Metode penelitian merupakan suatu kegiatan ilmiah, yang didasarkan pada metode, sistematika, dan pemikiran tertentu, yang bertujuan untuk mempelajari satu atau beberapa gejala hukum, dengan jalan menganalisanya. Penulis menggunakan jenis penelitian deksirptif ini karena penulis ingin memperoleh gambaran yang jelas dan memberikan data yang akurat tentang penyelesaian perkara tindak pidana penipuan yang dilakukan oleh anggota TNI. Pasal 9 Undang-Undang No. 31 Tahun 1997 tentang Peradilan Militer, diakitkan dengan Pasal 1 dan 2 Kitab UndangUndang Hukum Pidana Militer (KUHPM), maka Peradilan Militer mengadili tindak pidana didasarkan pada subyeknya, yaitu prajurit (militer) atau yang dipersamakan.
\end{abstract}

Kata Kunci: Military Criminal (Tindak pidana yang dilakukan oleh militer), Soldier (military) 


\section{PENDAHULUAN}

Undang- Undang menyebutkan bahwa Indonesia adalah negara hukum. Hal tersebut berarti bahwa negara Indonesia dalam menjalankan kehidupan berbangsa dan bernegara harus sesuai dengan aturan hukum yang berlaku. Negara Indonesia juga menjamin setiap warga negara bersamaan kedudukannya di dalam hukum dan pemerintahan dengan tidak ada kecualinya sebagaimana tercantum dalam pasal 27 ayat (1) UUD 1945 amandemen keempat. Dengan demikian sudah sewajarnya penegakan keadilan berdasarkan hukum dilaksanakan oleh setiap warga negara, setiap penyelenggara Negara, setiap lembaga kemasyarakatan termasuk kalangan militer.

Penegakan hukum di Indonesia sebagai wujud dari penyelenggaraan kekuasaan kehakiman sebagaimana diatur dalam Undang-undang No. 4 tahun 2004 dilaksanakan di empat lingkungan peradilan yaitu lingkungan peradilan umum, lingkungan peradilan agama, lingkungan peradilan tata usaha negara dan peradilan militer sesuai kewenangan absolutnya.

Dalam Undang-undang No: 48 tahun 2009 tentang Ketentuan-Ketentuan Pokok Kekuasaan Kehakiman ditetapkan bahwa salah satu penyelenggara kekuasaan kehakiman dilakukan oleh pengadilan dalam lingkungan peradilan militer, termasuk susunan serta acaranya diatur dalam Undang-undang tersendiri. Eksistensi pengadilan di lingkungan peradilan militer juga dimuat dalam Pasal 24 ayat (2) UUD 1945 amandemen keempat yang berbunyi kekuasaan kehakiman dilakukan oleh sebuah Mahkamah Agung dan badan peradilan dibawahnya dalam lingkungan peradilan militer, lingkungan peradilan agama, lingkungan peradilan tata usaha negara, lingkungan peradilan umum dan mahkamah konstitusi.

Tentara Nasional Indonesia (TNI) adalah bagian dari bangsa Indonesia yang bertanggung jawab dalam menjaga pertahanan keamanan negara.. Dalam melaksanakan tanggung jawabnya tersebut tentu saja ada kemungkinan penyimpangan yang dilakukan anggota
Tentara Nasional Indonesia. Bentuk penyimpangan itu antara lain pelanggaran Hak asasi manusia, pelanggaran hukum disiplin dan tindak pidana. Setiap tindak pidana yang dilakukan oleh anggota Tentara Negara Indonesia pada umumnya diselesaikan di Peradilan Militer kecuali oleh perwira penyerah perkara berpendapat bahwa tindak pidana tersebut diselesaikan melalui hukum disiplin.

Salah satu Tindak pidana yang cukup banyak dilakukan oleh anggota Tentara Nasional Indonesia adalah tindak pidana penipuan. Tindak pidana penipuan yang dilakukan oleh anggota Tentara Nasional Indonesia tentu tidak saja berkaitan perjalanan, kartu keamanan atau surat cuti orang lain sebagaimana yang diatur dalam Pasal 92 KUHP, tetapi juga bentuk-bentuk lain yang tidak diatur dalam KUHPT seperti penipuan membuat surat keterangan belum menikah, suratsurat berharga. Tindak pidana penipuan yang dilakukan oleh anggota tentara nasional Indonesia yang bertujuan mencari keuntungan pribadi atau golongan tertentu ini tentu saja merugikan bangsa dan negara. Untuk itu hukum harus dapat menertibkan setiap tindak pidana termasuk tindak pidana penipuan dengan cara memalsukan surat yang dilakukan oleh anggota Tentara Nasional Indonesia demi terwujudnya masyarakat Indonesian yang adil dan makmur.

"Era reformasi yang menuntut transparansi, kebebasan, demokratisasi dan persamaan hak, berimbas kepada penyelenggaraan peradilan. Prinsip equality before the law menghendaki tidak ada warga negara yang mendapat previelege apalagi dalam bidang peradilan. Oleh karena itu tuntutan bahwa militer yang melakukan tindak pidana umum diadili di peradilan umum terus bergaung dan puncaknya adalah dikeluarkannya TAP MPRI RI Nomor: VI/2000 dan TAP MPR RI Nomor: VIII/2000 Jo Undang-undang Nomor: 34 tahun 2004 yang menegaskan bahwa anggota militer yang melakukan kejahatan umum di bawa ke pengadilan sipil. Sedangkan Undang-undang Nomor 31 tahun 1997 tentang Peradilan Militer 
mengatakan tindak pidana yang dilakukan anggota militer baik tindak pidana umum sebagaimana diatur dalam KUHP dan perundang-undangan pidana lainnya, juga tindak pidana militer sebagaimana terdapat dalam KUHPM semuanya diadili di peradilan militer".

Secara yuridis eksistensi peradilan militer dimuat dalam "Pasal 24 ayat (2) UUD 1945 amandemen keempat yang berbunyi : kekuasaan kehakiman dilakukan oleh sebuah Mahkamah Agung dan badan peradilan yang berada dibawahnya dalam lingkungan peradilan umum, peradilan agama, lingkungan peradilan militer, lingkungan peradilan tata usaha negara dan oleh sebuah Mahkamah Konstitusi”.

Peradilan militer merupakan peradilan khusus baik obyek maupun subyeknya yaitu golongan rakyat tertentu (prajurit TNI atau yang dipersamakan). Kemudian pasal 1 dan 2 KUHPM mengatakan penerapan KUHP ke dalam KUHPM dan orang-orang yang tunduk kepada peradilan militer yang melakukan tindak pidana dan tidak tercantum dalam KUHPM diterapkan KUHP.

Ketetapan MPR RI Nomor VII/200o khususnya Pasal 3 ayat (4) huruf a berbunyi: "Prajurit TNI tunduk kepada kekuasaan peradilan umum dalam hal pelanggaran pidana umum. Kemudian UU Perubahan Undang-undang Nomor 31 tahun 1997 tentang peradilan militer menghendaki bahwa tindak pidana yang dilakukan oleh prajurit TNI diadili di peradilan umum."

\section{METODE PENELITIAN}

Penelitian adalah suatu metode ilmiah yang dilakukan melalui penyelidikan dengan seksama dan lengkap, terhadap semua bukti-bukti yang dapat diperoleh mengenai suatu permasalahan tertentu sehingga dapat diperoleh suatu pemecahan bagi permasalahan itu. Metode penelitian merupakan suatu kegiatan ilmiah, yang didasarkan pada metode, sistematika, dan pemikiran tertentu, yang bertujuan untuk mempelajari satu atau beberapa gejala hukum, dengan jalan menganalisanya (Dimyati, 2004 : 57) Penulis menggunakan jenis penelitian deksirptif ini karena penulis ingin memperoleh gambaran yang jelas dan memberikan data yang akurat tentang penyelesaian perkara tindak pidana penipuan yang dilakukan oleh anggota TNI.

\section{PERMASALAHAN}

Untuk mengurangi permasalahan ini, maka pembaharuan hukum harus diarahkan kepada pembangunan sistem hukum, yang meliputi struktur hukum, substansi hukum dan budaya hukum. Pembangunan struktur hukum dalam hal ini kelembagaan hukum harus diarahkan kepada terbentuknya satu lembaga hukum yaitu peradilan yang independen (Independence of Judiciary). Sebuah peradilah harus bebas dari pengaruh, direktiva, dan intervensi dari siapapun. Dan ini tercermin dari adanya kebebasan hakim dalam mengadili perkara pidana, kebebasan hakim tidak mungkin terjadi apabila masih terikat rantai komando atau adanya hubungan yang sub ordinasi. Pembangunan substansi hukum harus diarahkan kepada pembentukan suatu undang-undang yang komprehensif, dalam hal ini perubahan undang-undang peradilan harus diikuti dengan perubahan dalam hukum materil, hukum formil dan hukum pelaksanaann pidana. Sinkronisasi perlu dilakukan sebelum terbentuknya undang-undang peradilan pidana militer yang baru yaitu UUD 1945, Undangundang kekuasaan kehakiman, Undangundang Mahkamah Agung dan Undangundang pemasyarakatan.

Menentukan perbuatan mana yang dikategorikan sebagai tindak pidana umum oleh seorang prajurit TNI, pertama-tama bisa dilihat dalam KUHP dan perundang-undangan lainnya. Pelanggaran terhadap ketentuan ini harus diadili di peradilan umum. Sedangkan perbuatan yang menyangkut kehormatan korps dan pelanggaran ketentuan pidana umum yang luar biasa misalnya genocide, pelanggaran terhadap hukum perang di peradilan Militer. Memilah-milah mana yang merupakan pelanggaran terhadap hukum pidana umum dan mana pelanggaran yang hanya bisa dilakukan oleh seorang militer merupakan persoalan 
utama yang harus terlebih dahulu dibicarakan/dilakukan

\section{PEMBAHASAN}

Walaupun sebagai warga negara Republik Indonesia, Tentara bukanlah golongan tersendiri karena tiap anggota TNI merupakan bagian dari masyarakat biasa, namun yang membedakan adalah adanya kewajiban TNI sebagai inti dari pembelaan dan pertahanan negara. Maka diperlukan suatu pemeliharaan ketertiban yang lebih disiplin dalam organisasinya, sehingga seolah-olah merupakan golongan tersendiri dalam rangka melaksanakan tugas pokoknya yang sangat besar tersebut. Oleh karena itu bagi golongan militer diperlukan suatu hukum khusus dan peradilan yang terpisah dari Peradilan Umum. Kekhususan itu adalah bahwa masyarakat tentara itu adalah pengkhususan daripada masyarakat umum (Salam, 1996 : 11). Hukum pidana militer sebagai bagian dari hukum militer merupakan hukum khusus, karena dilihat dari pengertiannya untuk membedakan dengan hukum pidana umum dan hukum acara pidana umum yang berlaku untuk setiap orang.

Hukum pidana militer ditinjau dari arti materiil dan formal adalah bagian dari hukum positif, yang berlaku bagi justiabel militer, yang menentukan dasar-dasar dan peraturan-peraturan tentang tindakantindakan yang merupakan larangan dan keharusan serta terhadap pelanggarannya diancam dengan pidana, yang menentukan dalam hal apa dan bilamana pelanggar dapat dipertanggungjawabkan atas tindakannya dan yang menentukan juga cara penuntutan, penjatuhan pidana dan pelaksanaan pidana, demi tercapainya ketertiban hukum.

Dari pengertian di atas mengenai hukum pidana militer dapat dijelaskan bahwa pengertian tersebut didasarkan kepada terhadap siapa hukum pidana tersebut berlaku. Dengan kata lain, apabila ditinjau dari sudut justiabel, dalam hal ini militer (dan yang dipersamakan) maka Hukum Pidana Militer adalah salah satu hukum pidana yang secara khusus berlaku bagi militer (dan yang dipersamakan) disamping berlakunya hukum pidana lainnya. Hukum pidana militer memuat peraturanperaturan yang menyimpang dari ketentuan-ketentuan yang telah diatur dalam hukum pidana umum dan hanya berlaku juga bagi golongan khusus (militer) atau orang-orang karena peraturan ditundukkan padanya."Siapa siapa saja yang diberlakukan hukum pidana tentara diatur dalam Pasal 46, 47 ayat (1), 49 ayat 92) dan pasal 50 Kitab Undang-undang Hukum Pidana Militer"

Dengan adanya hukum pidana militer, bukan berarti anggota militer yang melakukan tindak pidana tidak dapat diberlakuan hukum pidana umum. Bagi militer dapat berlaku baik hukum pidana umum maupun hukum pidana militer, seperti diatur dalam Pasal 1 KUHPM :

"Pada waktu memakai kitab undang-undang ini berlaku aturan -turan pidana umum, termasuk bab ke sembilan dari buku pertama, kecuali aturan yang menyimpang yang ditetapkan oleh undang-undang"

Diperlukan hukum khusus bagi anggota militer, karena untuk pelanggaran tindak pidana tertentu, apabila diberlakukan hukum pidana umum, dirasakan ancaman hukumannya terlalu ringan. Misalnya tindak pidana pencurian yang dilakukan oleh anggota militer di dalam kesatrian atau asrama militer. Sedangkan untuk perbuatan-perbuatan yang hanya dapat dilakukan oleh militer saja, seperti desersi, menolak perintah dinas, dan sebagainya, tidak diberlakukan hukum pidana umum. Apabila hal-hal tersebut dimasukkan ke dalam KUHP, akan membuat KUHP sukar dipergunakan 
karena terhadap ketentuan-ketentuan ini hanya tunduk sebagian kecil dari anggota masyarakat, juga pengadilan yang berhak mengadili militer adalah peradilan tersendiri yaitu Pengadilan Militer (Yasin, 1995 : 70-71).

Apabila ada seorang anggota TNI melakukan tindak pidana yang tidak diatur dalam KUHPM tetapi diatur dalam KUHP, maka ia dapat dikenai hukuman sebagaimana yang diatur dalam KUHP. Apabila seorang anggota TNI melakukan tindak pidana yang sama terdapat dalam KUHPM dan juga diatur dalam KUHP maka yang digunakan adalah hukum pidana militer. Karena ini sesuai dengan asas "Lex Specialis Derogate Legi Generalis" yang artinya bahwa undnagundang atau hukum yang bersifat khusus mengesampingkan undang-undang atau hukum yang bersifat umum. Berhubung hukum pidana militer merupakan hukum yang khusus dari hukum pidana umum, maka yang diberlakukan adalah hukum pidana militer. Berhubung subjek dari pelaku adalah anggota militer maka yang berhak mengadili adalah Pengadilan Militer oleh Hakim Militer.

Untuk tindak pidana tertentu seperti perkara koneksitas seorang militer dapat diadili di Pengadilan Umum dan sebaliknya seorang sipil dapat diadili di pengadilan Miiter, sesuai dengan Pasal 3,4 UU no, 5 tahun 1950 tentang Susunan dan Kekuasaan Badan -badan Peradilan Militer, sebagai berikut :

1. Titik berat kerugian

Apabila titik berat kerugian yang ditimbulkan dari tindak pidana yang terjadi lebih berat kepentingan umum maka pengadilan umum yang menyidangkan, dan apabila sebaliknya kepentingan militer yang lebih berat maka Pengadilan Militer yang menyidangkan.

2. Sifat kejahatan
Apakah kejahatan yang terjadi itu bersifat umum atau militer

3. Peranan dan jumlah pelaku

Apakah jumlah pelaku tindak pidana lebih banyak militer atau sebaliknya dan siapa yang lebih banyak berperan.

Komposisi Hakim dalam hal menyidangkan perkara tersebut baik itu di Pengadilan Militer atau di Pengadilan Negeri diadakan komposisi gabungan yang terdiri dari Hakim Militer dan Hakim sipil.

Dapat diambil kesimpulan bahwa yang berlaku bagi seorang militer (atau justiabel peradilan militer) bukan saja hanya hukum pidana militer melainkan juga hukum pidana umum dan ketentuan -ketentuan yang terdapat dalam hukum pidana umum (yang pada dasarnya digunakan dalam hukum pidana militer dengan beberapa pengecualian). Oleh karena itu, diperlukan penegak-penegak hukum yang berkecimpung dalam badanbadan peradilan militer harus menguasai baik ilmu hukum pidana militer juga harus menguasai hukum pidana umum agar dapat menangani masalah hukum secara adil.

Oditur dalam perkara ini mengajukan tuntutan sebagai berikut : memohon agar pengadilan militer menyatakan terdakwa terbukti bersalah melakukan tindak pidana pemalsuan surat sebagaimana diatur dan diancam pidana menurut Pasal 263 KUHP ayat (1) KUHP. Dengan mengingat Pasal 263 KUHP dan Pasal 182 ayat (1) Undang-undang No 31 Tahun 1997

\section{Pengadilan Militer Dalam Sistem Hukum Pidana Indonesia}

Keberadaan hukum pidana khusus sesungguhnya tidak dapat dilepaskan dari kekhususan-kekhususan yang terdapat dalam hukum pidana yang bersangkutan. Sudarto mengemukakan bahwa kekhususan dari hukum pidana khusus 
terletak pada adanya ketentuan-ketentuan yang menyimpang dari hukum pidana umum yang menyangkut sekelompok orang atau perbuatan-perbuatan tertentu (Sudarto, 2006 : 61). Kekhususan dari hukum pidana militer tidak dapat disangkal dan tampak jelas, karena berlaku bagi golongan orang-orang tertentu, yaitu militer.

Pandangan yang sama dikemukakan oleh Loebby Loqman bahwa kekhususan dari hukum pidana khusus terletak pada pengaturan perbuatan yang hanya dilakukan oleh orang-orang tertentu, misalnya hukum pidana militer yang berlaku bagi militer. Selain itu, hukum pidana khusus dapat dimaknai pula sebagai hukum pidana yang mengatur suatu tindak pidana yang mempunyai sifat khusus. Bertolak dari pengertian hukum pidana umum dan hukum pidana khusus di atas, apabila dilihat dari subyek berlakunya hukum pidana, maka hukum pidana umum dalam dapat diberikan pengertian sebagai hukum pidana yang dibuat oleh pembentuk undang-undang dan diberlakukan secara umum kepada semua warga negara, termasuk militer. Dengan demikian, hukum pidana umum ini memiliki ruang

Dalam hukum pidana umum (KUHP dan peraturan perundangundangan pidana lain di luar KUHP) maupun hukum pidana militer (KUHPM) pada dasarnya diatur dan dirumuskan perbuatan-perbuatan tertentu yang dilarang dan diancam dengan sanksi berupa pidana. Perbuatan-perbuatan yang demikian itu sering dikenal dengan istilah "perbuatan pidana" atau "tindak pidana". Istilah tindak pidana sebenarnya merupakan pengganti atau terjemahan dari kata "strafbaar feit" dalam bahasa Belanda. Dalam peraturan perundangundangan di Indonesia dijumpai pula istilah-istilah lain yang dimaksudkan sebagai terjemahan dari "strafbaar feit".
Istilah- istilah tersebut adalah "peristiwa pidana” yang digunakan dalam UndangUndang Dasar Sementara Tahun 1950, "perbuatan pidana" yang digunakan dalam Undang- Undang Nomor 1 Tahun 1951, "perbuatan-perbuatan yang dapat dihukum" yang digunakan dalam UndangUndang Darurat Nomor 2 Tahun 1951 dan "tindak pidana" yang telah digunakan dalam peraturan perundang-undangan di Indonesia dewasa ini, seperti UndangUndang Darurat Nomor 7 Tahun 1955, Undang-Undang Nomor 31 Tahun 1999, Undang-Undang Nomor 15 Tahun 2003, Undang-Undang Nomor 21 Tahun 2007, Undang-Undang Nomor 8 Tahun 2010 dan sebagainya.

Menurut Sudarto, "pemakaian istilah yang berbeda-beda di atas sebaiknya tidak perlu dipersoalkan, sepanjang mengetahui isi dari pengertian istilah tersebut. Tindak pidana merupakan suatu pengertian dasar dalam hukum pidana. Tindak pidana adalah suatu pengertian yuridis yang berbeda dengan istilah "perbuatan jahat" atau "kejahatan" yang dapat diartikan secara yuridis atau kriminologis. Pengertian tindak pidana sendiri tidak terdapat kesatuan pendapat di antara para sarjana. Namun demikian, pandangan mengenai pengertian tindak pidana tersebut dapat dibedakan menjadi pandangan monistis dan pandangan dualistis. Aliran dualistis memisahkan pengertian tindak pidana dan pertanggungjawaban pidana, sedangkan aliran monistis tidak memisahkan keduanya" (Sudarto, Hukum Pidana I, $1990: 39-40$ ).

Moeljatno lebih sependapat menggunakan istilah perbuatan pidana dan memberikan pengertian perbuatan pidana sebagai perbuatan yang dilarang oleh suatu aturan hukum dan disertai dengan ancaman (sanksi) yang berupa pidana tertentu, bagi barang siapa melanggar larangan tersebut. Dengan kata lain, perbuatan pidana adalah perbuatan 
yang oleh suatu aturan hukum dilarang dan diancam dengan pidana. Larangan tersebut ditujukan terhadap perbuatan (suatu keadaan atau kejadian yang ditimbulkan oleh kelakuan orang), sedangkan ancaman pidananya ditujukan terhadap orang yang melakukan perbuatan.

Bertolak dari pengertian singkat tindak pidana atau perbuatan pidana ini dapat dikemukakan bahwa tindak pidana yang diatur dan dirumuskan dalam hukum pidana umum (KUHP maupun peraturan perundang-undangan pidana lain di luar KUHP) dapat disebut sebagai "tindak pidana umum", sedangkan tindak pidana yang diatur dan dirumuskan dalam hukum pidana militer (KUHPM) dapat disebut dengan "tindak pidana militer". Apabila berpedoman pada pengertian hukum pidana umum sebagai hukum pidana yang dibuat oleh pembentuk undang-undang dan diberlakukan kepada setiap orang pada umumnya, maka hukum pidana umum di Indonesia dapat mencakup ruang lingkup yang cukup luas. Hal tersebut disebabkan karena hukum pidana umum dapat ditemukan pengaturannya dalam Kitab UndangUndang Hukum

Pidana (KUHP) maupun peraturan perundang-undangan pidana lain di luar KUHP. Meskipun peraturan perundangundangan pidana di luar KUHP mengatur tindak pidana tertentu, namun dapat dikategorikan sebagai hukum pidana umum, karena peraturan perundangundangan pidana tersebut berlaku bagi semua warga negara, baik sipil maupun militer.

Dengan diterapkannya asas unity of command di bidang hukum, maka kemungkinan terjadinya bentrokan adalah sangat kecil sekali. Hal ini terlihat bilamana terjadi suatu tindak pidana yang dilakukan oleh seorang anggota militer dan suatu kesatuan, maka disamping mengganggu kepentingan TNI itu sendiri, juga akan mengganggu kepentingan masyarakat umum. Sebab kepentingan TNI itu pada hakikatnya juga adalah kepentingan masyarakat umum Anggota militer yang melakukan tindak pidana berlaku ketentuanketentuan Hukum Pidana Umum, namun bagi militer terdapat ketentuanketentuan yang menyimpang dari ketentuan-ketentuan yang diatur di dalam KUHP yang khusus diberlakukan bagi militer. Ketentuan-ketentuan yang khusus itu diatur di dalam Kitab Undang-Undang Hukum Pidana Militer (KUHPM) yang hal tersebut merupakan penambahan dari aturan-aturan yang telah diatur di dalam KUHP.

Tekad Prajurit Tentara Nasional Indonesia untuk mempertahankan Negara Kesatuan Republik Indonesia, mengamalkan serta melestarikan Pancasila dan Undang-Undang Dasar 1945 diwujudkan dalam Sapta Marga dan Sumpah Prajurit. Disiplin prajurit mutlak harus ditegakan demi tumbuh dan berkembangnya Tentara Nasional Indonesia dalam mengemban dan mengamalkan tugas yang telah dipercayakan oleh bangsa dan negara kepadanya. Oleh karena itu, sudah menjadi kewajiban setiap prajurit untuk menegakan disiplin. Penegakan disiplin dikalangan prajurit, harus dilaksanakan oleh setiap anggota tanpa melihat pangkat serta kedudukan. Upaya penegakan disiplin di dalam tata kehidupan Tentara Nasional Indonesia memerlukan suatu tatanan disiplin prajurit berupa UndangUndang No: 25 tahun 2014 tentang Hukum Disiplin Prajurit. Hal ini didasarkan, karena untuk pelanggaran tindak pidana tertentu, ancaman hukumannya dirasakan terlalu ringan kalau hanya berlaku hukum pidana umum.Tindak pidana militer pada umumnya dalam Kitab Undang-Undang Hukum Pidana Militer dibagi menjadi dua bagian yaitu: 
1) Tindak pidana militer murni adalah tindakan-tindakan terlarang atau diharuskan yang pada prinsipnya hanya mungkin dilanggar oleh seorang militer, karena keadaannya yang bersifat khusus atau karena suatu kepentingan militer menghendaki tindakan tersebut ditentukan sebagai tindak pidana.

2) Tindak pidana militer campuran adalah tindakan-tindakan terlarang atau diharuskan yang pada pokoknya sudah ditentukan dalam perundangxii undangan lain, akan tetapi diatur lagi dalam Kitab Undang-Undang Hukum Pidana Militer karena adanya sesuatu keadaan yang khas militer atau karena adanya sesuatu sifat yang lain, sehingga diperlukan ancaman pidana yang lebih berat bahkan mungkin lebih berat dari ancaman pidana pada kejahatan semula dengan pemberatan tersebut.

Untuk menyelesaikan setiap tindak pidana militer yang terjadi jelas diperlukan juga hukum acara pidana militer yang akan memuat mengenai proses pemeriksaan suatu perkara pidana militer di dalam suatu pengadilan. Dalam Undang-undang No.31 Tahun 1997 tentang Peradilan Militer, dikemukakan mengenai kewenangan peradilan militer untuk menyelesaikan perkara pidana yang dilakukan oleh anggota Tentara Nasional Indonesia.Peradilan Militer selain itu juga dapat mengadili tuntutan ganti rugi dan sengketa tata usaha di lingkungan militer.

Pengadilan dalam lingkungan peradilan militer merupakan badan pelaksana kekuasaan kehakiman dilingkungan militer dan berpuncak pada mahkamah agung sebagai pengadilan tertinggi. Pengadilan ini secara organisatoris dan administrasif berada dibawah pembinaan panglima. Pembinaan tersebut tidak boleh mengurangi kebebasan hakim dalam memeriksa dan memutus perkara. Pengadilan dalam peradilan militer terdiri dari :

1. Pengadilan Militer.

Memeriksa dan memutus pada tingkat pertama, terdakwa merupakan prajurit berpangkat kapten kebawah diatur dalam Pasal 9 UU No 31 tahun 1997 yang harus diadili pengadilan militer.

2. Pengadilan Militer Tinggi.

Pengadilan ini juga memeriksa dan memutus pada tingkat pertama, terdakwa yang berpangkat mayor ke atas dan menyelesaikan sengketa tata usaha militer, juga memeriksa dan memutus tingkat banding dari pengadilan militer dalam daerah hukumnya.

3. Pengadilan Militer Utama.

Memeriksa dan memutus pada tingkat banding perkara pidana terdakwa yang berpangkat mayor ke atas dan tata usaha militer yang diputus pengadilan militer tinggi. Pengadilan ini juga memutus perbedaan pendapat antara Perpera dan oditur mengenai diajukan atau tidak perlunya suatu perkara pada lingkungan peradilan umum atau peradilan militer

4. Pengadilan Militer Pertempuran. Memeriksa dan memutus pada tingkat pertama dan terakhir perkara pidana yang dilakukan terdakwa di daerah pertempuran. Dengan keberadaan Peradilan militer di Indonesia, diharapkan dapat meminimalisir pelanggaran disiplin oleh anggota Tentara Nasional Indonesia. Peradilan bukan hanya menjadi upaya represif, namun juga sebagai upaya preventif untuk mencegah adanya pelanggaran disiplin atau tindak pidana yang dilakukan oleh anggota militer. 
Dalam peradilan militer, oditur sebagai penuntut umum memiliki kewajiban untuk membuktikan tindak pidana yang dilakukan oleh anggota militer.Pembuktian dalam peradilan militer maka harus mendasarkan pada alat bukti yang sah yang diatur dalam Pasal 172 Undang-Undang 31 Tahun 1997 tentang Peradilan Militer. Tindak pidana insubordinasi merupakan tindak pidana berupa perlawanan dari bawahan terhadap atasan yang lebih tinggi pangkatnya. Tindak pidana Insubordinasi ini biasanya dilakukan akibat dari reaksi bawahan tersebut terhadap perlakuan atasan kepadanya, sehingga sangat bersifat spontan sekali dan jarang ditemui alat bukti. Adapun alat bukti yang ada biasanya hanya keterangan saksi, sedangkan saksi dalam tindak pidana militer merupakan anggota militer yang berada dalam suatu kesatuan yang pada dasarnya menjunjung tinggi kesetiakawanan

\section{Tindak Pidana Penipuan}

Pertanggungjawaban militer dari pengertian umum merupakan suatu bentuk pertanggung jawaban seseorang atas tindakan yang dilakukan yang memiliki unsur melawan hukum, sedangkan untuk pertanggungjawaban dalam pidana adalah suatu bentuk pemidanaan seorang pelaku delik dengan arti apakah seorang tersangka dapat dipertanggungjawabkan atas satu delik atau tidak pidana.

Penipuan menurut KUHP terdapat dalam pasal 378 yakni "barang siapa dengan maksud hendak menguntungkan diri sendiri atau orang lain dengan melawan hak, baik dengan memakai nama palsu atau keadaan palsu, baik dengan akal dan tipu muslihat, maupun dengan karangan perkataan-perkataan bohong, membujuk orang supaya memberikan sesuatu barang, membuat utang atau menghapuskan piutang, dihukum karena penipuan, dengan hukuman penjara selama-lamanya empat tahun".

Pasal 65 ayat (2), bahwa "prajurit tunduk kepada kekuasaan peradilan militer dalam hal pelanggaran hukum pidana militer dan tunduk pada kekuasaan peradilan umum dalam hal pelanggaran hukum pidana umum yang diatur dengan Undang-undang." Meski begitu sejauh ini militer tetap diadili di peradilan militer, apapun masalahnya. Penyebabnya adalah tersedianya celah pada Pasal 74 aturan yang sama.

Dalam ayat (1) pasal tersebut tertulis, "ketentuan sebagaimana dimaksud dalam pasal 65 berlaku pada saat Undang-undang tentang peradilan militer yang baru diberlakukan." Sementara ayat (2) tertulis "Selama Undang-undang peradilan militer yang baru belum dibentuk, tetap tunduk pada ketentuan Undang-undang Nomor 31 Tahun 1997 tentang Peradilan Militer.

Berdasarkan undang-undang nomor 6 tahun 1950 peranan komandan selaku Ankum tidak banyak berperan, dapat saja seorang tersangka sudah dijatuhi hukuman oleh pengadilan tanpa sepengetahuan dari Ankum yang bersangkutan. Ankum akan kehilangan anak buahnya yang dihukum tanpa sepengetahuannya, hal ini akan mempengaruhi mobilitas dari suatu kesatuan.

Dengan sistem ini wewenang Ankum sebagai penanggung jawab daripada kesatuannya merasa dilampaui dan akan menimbulkan salah pengertian antara komandan selaku penanggung jawab keamanan dan ketertiban disatu pihak dengan Oditur yang bertanggungjawab menegakkan hukum di lain pihak. Untuk menjaga jangan sampai terjadi bentrokan antara Oditur dan komandan maka dalam perkembangannya melihat kondisi dan kebutuhan peradilan militer itu sendiri, lahirlah undangundang nomor 29 tahun 1954 tentanng 
pertahanan Negara Republik Indonesia yang dalam pasal 35 menyebutkan "Angkatan Perang mempunyai peradilan tersendiri dan komandan mempunyai hak penyerah perkara".

Sebagai realisasi dari isi pasal 35 itu kemudian lahirlah undang-undang nomor 1 Drt tahun 1958 mengenai Hukum Acara Pidana Tentara yang merubah undang-undang nomor 6 tahun 1950. dengan adanya undang-undang tersebut maka Ankum harus ikut menentukan nasib anak buahnya dalam rangka penyelesaian kasus pidana dan membatasi ikut campur pihak lain di dalam kesatuannya.

Dengan berlakunya undang-undang nomor 1 Drt tahun 1958, wewenang Oditur berpindah ketangan komandan. Berpindahnya wewenang sebagai pengusut, penuntut dan penyerah perkara kepada komandan, maka fungsi jaksa tentara dikurangi yang tadinya bersifat aktif menjadi pasif. Karena situasi politik semakin stabil, maka kehidupan militer semakin mantap hingga terpikir untuk mengadakan penggantian terhadap tenaga Hakim dan Jaksa Tentara yang masih dirangkap Hakim dan Jaksa Pengadilan Negeri dengan tenaga Militer yang aktif ahli hukum. Untuk mendapatkan tenaga ahli hukum dikalangan militer maka pada tahun 1952 didirikan Akademi Hukum Militer dan Perguruan Tinggi Hukum Militer.

Setelah didapatkan tenaga aktif yang berpendidikan hukum, mulai tahun 1961 diadakan penggantian terhadap tenaga-tenaga Hakim, Jaksa Tentara dari Pengadilan Negeri dengan tenaga-tenaga aktif tersebut. Penggantian tenaga tersedia didasarkan dari instruksi Menteri Jaksa Agung No. 157/MDJAG/1961/SI tanggal 11 April 1961 yang menginstruksikan kepada semua jaksa tentara Pengadilan Negeri menyerahkan tugas rangkapan mereka kepada tenaga-tenaga Jaksa Tentara yang berasal dari ABRI.
Hal ini menyempurnakan prinsip unity of command sejajar dengan kehendak Undang-Undang nomor 29 tahun 1954, pada 19 September 1961 lahirlah Surat Keputusan Bersama KASAD dan Menteri Jaksa Agung Nomor MK/KPTS-189/9/1961 dimana Menteri Jaksa Agung mengalihkan wewenang, kekuasaan dan tanggung jawabnya yang berhubungan dengan kejaksaan tentara. Sesuai Pasal 9 Undang-Undang No. 31 Tahun 1997 tentang Peradilan Militer, diakitkan dengan Pasal 1 dan 2 Kitab Undang-Undang Hukum Pidana Militer (KUHPM), maka Peradilan Militer mengadili tindak pidana didasarkan pada subyeknya, yaitu prajurit (militer) atau yang dipersamakan. Dengan kata lain, selama ia militer, dan melakukan tindak pidana apa saja, baik tindak pidana militer (murni), seperti desersi, insubordinasi, dan lain-lain juga tindak pidana umum, seperti perampokan, pemerkosaan, pembunuhan, atau pencurian, dan lainlain maupun tindak pidana khusus, seperti penyalahgunaan psikotropika/shabushabu, narkotika, korupsi, dan lain-lain diadili di peradilan militer yang tidak ada kaitannya sama sekali dengan tugastugas/jabatan kemiliteran.

Meskipun bukan prajurit atau yang dipersamakan dengan prajurit melakukan tindak pidana, dan tindak pidana tersebut merugikan kepentingan militer serta dilakukan semata-mata dengan militer (perkara koneksitas) dapat diadili di peradilan militer. Apabila orang sipil (di luar PNS TNI) dapat diadili oleh peradilan militer, maka PNS TNI yang melakukan tindak pidana yang merugikan TNI seharusnya dapat diadili oleh peradilan militer. Sebagaimana ketentuan yang mengatur tentang koneksitas, maka titik berat diadilinya seseorang warga sipil (civilian) di peradilan militer, karena unsur (kerugian) militer melebihi unsur sipil, sebagaimana Penjelasan Pasal 22 
Undang-undang Nomor : 14 Tahun 1970, sebagai berikut :

Penyertaan pada suatu delik militer yang murni oleh seorang bukan militer dan perkara penyertaan, di mana unsur militer melebihi unsur sipil misalnya, dapat dijadikan landasan untuk menetapkan Pengadilan lain dari pada Pengadilan Umum, ialah Pengadilan Militer untuk mengadili perkara-perkara demikian. Dengan demikian, selama akibat tindak pidana tersebut dapat dibuktikan merugikan kepentingan militer, misalnya pencurian senjata/amunisi di gudang senjata, membunuh caraka untuk memperoleh data/informasi militer, membakar gedung arsip/dokumen militer, dan lain-lain, maka pelaku akan diadili di Peradilan Militer.

\section{PENUTUP}

\section{Kesimpulan}

Dari uraian diatas bahwa secara tegas dan jelas terkait dengan Pertanggungjawaban militer dari pengertian umum merupakan suatu bentuk pertanggung jawaban seseorang atas tindakan yang dilakukan yang memiliki unsur melawan hukum, sedangkan untuk pertanggungjawaban dalam pidana adalah suatu bentuk pemidanaan seorang pelaku delik dengan arti apakah seorang tersangka dapat dipertanggungjawabkan atas satu delik atau tidak pidna, sehubungan dengan tindak pidana penipuan maka sebagai landasan hukumnya menggunakan hukum KUHP pasal 378 yakni barang siapa dengan maksud hendak menguntungkan diri sendiri atau orang lain dengan melawan hak, baik dengan memakai nama palsu atau keadaan palsu, baik dengan akal dan tipu muslihat, maupun dengan karangan perkataan-perkataan bohong, membujuk orang supaya memberikan sesuatu barang, membuat utang atau menghapuskan piutang, dihukum karena penipuan, dengan hukuman penjara selama-lamanya empat tahun. Peradilan Militer menjadi suatu wadah dalam penertiban berkelanjutan yang terdapat dalam ruang lingkup militer, sehingga satuan pertahanan bukanlah sipil yang sama dalam konteks lembaga peradilannya.

\section{Saran}

Seharusnya dimana dalam pengimplementasiannya harus sesuai Pasal 9 Undang-Undang No. 31 Tahun 1997 tentang Peradilan Militer, diakitkan dengan Pasal 1 dan 2 Kitab UndangUndang Hukum Pidana Militer (KUHPM), maka Peradilan Militer mengadili tindak pidana didasarkan pada subyeknya, yaitu prajurit (militer) atau yang dipersamakan. Dengan kata lain, selama ia militer, dan melakukan tindak pidana apa saja, baik tindak pidana militer (murni), seperti desersi, insubordinasi, dan lain-lain juga tindak pidana umum, seperti perampokan, pemerkosaan, pembunuhan, atau pencurian, dan lain-lain. Peradilan militer harus juga dibuat dengan penuh standard transparansi dan independensi layaknya lembaga peradilan pada umumnya, mengingat bahwa peradilan militerpun harus tunduk dan patuh kepada suatu pengaturan yang tertuang dalam lembaga peradilan tertinggi yaitu Mahkamah Agung dalam proses hierarki atas strukturisasi yang tercantum pada proses, tata cara serta implementasi.

\section{DAFTAR PUSTAKA}

Khudzalifah Dimyati, Kelik Wardiono, Metode Penelitian Hukum, Surakarta: Fakultas Hukum Universitas Muhammadiyah Surakarta, 2004

Moch, Faisal Salam, Hukum Acara Pidana Militer Di Indonesia, Mandar Maju, Bandung, 1996 
Sukemi. H.M Ysin, "Pemecatan Dari Dinas Militer Bagi Seorang Prajurit Akibat Dari Putusan Hakim”, Majalah Yudhagama, 21 (maret, 1995)

Sudarto, Kapita Selekta Hukum Pidana, Alumni, Bandung,2006

Loebby Loqman, Delik Politik di Indonesia, Ind-Hill-Co., Jakarta, 1993
Sudarto,Hukum Pidana I, Yayasan

Sudarto, Semarang, 1990 